\title{
Hypopituitarism and hepatitis e genotype 3 infection - first case report and review on immunocompetence in hypopituitarism
}

\begin{abstract}
We studied the course of acute hepatitis E virus infection [HEV] in a German patient under stable hormonal replacement therapy for hypopituitarism. The 75-year-old male patient had acute hepatitis E with positive immunoglobulins [IgG and IgM] as well as HEV RNA Genotype 3c detection. Serum transaminases rose in $3 / 17$ and spontaneously dropped to pre-infection levels after dose escalation of the hydrocortisone. Although there is data in the medical literature, that panhypopituitaric patients even under stable hormonal replacement regimens have immune deficiency, their immune competence seems to be sufficient to overcome acute hepatitis E infection.
\end{abstract}

Keywords: hepatitis e, hypopituitarism, panhypopituitarism, hydrocortisone, cortisone replacement therapy, hepatitis e genotype 3
Volume 3 Issue 7 - 2017

\author{
Igor Alexander Harsch, Peter Christopher \\ Konturek \\ Department of Internal Medicine II,Teaching Hospital of the \\ University of Jena, Germany
}

\begin{abstract}
Correspondence: Igor Alexander Harsch, Thuringia Clinic Saalfeld "Georgius Agricola", Department of Internal Medicine II, Division of Endocrinology and Metabolism, Teaching Hospital of the University of Jena, Rainweg 68, D-073/8 Saalfeld/Saale, Germany, Tel +49[0]367I/54I569, Fax +49[0]367I/54I403, Email iharsch@thueringen-kliniken.de
\end{abstract}

Received: December II, 2017 | Published: December 21, 2017

\section{Introduction}

In the last decades, hepatitis E virus infection [HEV] had often been regarded as a disease limited to the tropics. Infections with the tropical HEV genotypes 1 and 2 are mainly transmitted fecal-orally by contaminated drinking water. ${ }^{1}$ In the Middle East and North African regions, the seroprevalence of HEV in the general population ranged from 2.0 to $37.5 \%$ and was higher in males than in females. ${ }^{2} \mathrm{HEV}$ genotype 3 is also endemic in Europe and an under diagnosed and emerging public health issue. In industrialized countries, domestic pigs are the main carriers of hepatitis $\mathrm{E}$ and wild boars can also carry the virus. That said, the consumption of raw or undercooked pork meat and liver is the most common cause of hepatitis $\mathrm{E}$ infection in these regions. In the vast majority of patients, the infection is either clinically silent or has a benign self-limiting course. ${ }^{1}$ However, immunosuppressed individuals, such as transplant recipients or patients with human immunodeficiency virus [HIV]-infection, are at risk for developing a fulminant course of chronic hepatitis $\mathrm{E}$, that may eventually lead to liver fibrosis and cirrhosis. ${ }^{1}$ The rise in hepatitis E infection in industrialized countries will lead to an increased number of infections in patients with other comorbidities, some of them with a negative impact on immune function and thus, at risk for a more complicated course of HEV infection. Among these could be hypopituitarism. The immune function and immunocompetence in hypopituitaric patients is still a matter of debate..$^{3-5}$ There is a wide body of literature on immunological perturbations in animal models with deficiency or excess of pituitary hormones. ${ }^{6}$ However, in humans, the situation is not that clear: E.g. Mukherjee et al. ${ }^{4}$ reported significant humoral immune deficiency in twenty-one panhypopituitary patients although they were under stable pituitary hormone replacement. The reduced immune function accounted most strikingly in patients with low insulin-like growth factor 1 levels, which was not reproduced in more recent studies. ${ }^{5,7}$ The case of a patient with panhypopituitarism under pituitary hormone replacement with acute hepatitis $\mathrm{E}$ is reported. Such cases to our knowledge have not been reported before.

\section{Case report}

A 75-year-old male patient had maculopapulous exanthema in the gluteal region, as well as the extremities on 17.3.2017. The exanthema was non-itching and self-limiting the next day. General exhaustion, nausea and low appetite followed since 19.3.2017. The general practitioner had detected an increase in liver transaminases. Upon admission to our clinic he was fully conscious and not icteric. He had not stayed abroad since September 2016. Important in his medical history was well-controlled hypertension, treated with Valsartan $160 \mathrm{mg} /$ die and Hydrochlorothiazide $12.5 \mathrm{mg} /$ die. Furthermore, he underwent transsphenoidal pituitary surgery due to an endocrine inactive pituitary adenoma in 10/2003. Due to recurrence, stereotactic radiation therapy with $30 \times 1.8$ Gray was performed between 6-7/2004, leaving the patient panhypopituitaric. The present replacement therapy was levothyroxine $75 \mu \mathrm{g}$ daily, hydrocortisone $15-10-0 \mathrm{mg}$ and testosteroneenanthate in a transdermal gel formulation with $25 \mathrm{mg}$ daily. Non-alcoholic fatty liver disease [NAFLD] with a slightly elevated gamma glutamyltransferase [Gamma GT] in a range between 2-4 U/1 [normal value $<1 \mathrm{U} / 1$ ] and steatosis hepatis in ultrasound scan was a suspected diagnosis since the nineties, liver biopsy had not been done. Due to dyslipidemia, he was also treated with Simvastatin $40 \mathrm{mg} /$ die since years. Although an unlikely culprit, this therapy was halted after admission. Physical examination showed an overweight [BMI $30 \mathrm{~kg} / \mathrm{m}^{2}$ ], non-icteric patient. He was normotensive and had a rhythmic heart action. He was normally hydrated and had no signs of exsiccosis. Furthermore, there were no pathological findings at the lung. The liver was enlarged, not painful. The neurological examination was normal.

Laboratory analysis of liver function 3/17: pathological were the levels of gamma GT, alanine aminotransferase [ALAT], aspartate aminotransferase [ASAT] and bilirubin. The course of the enzymes are shown in Figure 1. The serum was negative for antinuclear antibodies, and c -and p-anti-neutrophilic cytoplasmatic antibodies 
[ANCA]. Serologic testing for hepatitis A, B and C was negative. Antibodies against hepatitis $\mathrm{E}$ virus $[\operatorname{IgG}$ and $\operatorname{IgM}]$ were positive, as well as the HEV RNA detection [polymerase chain reaction]. The genotype was $3 \mathrm{c}$. The patient did not report recent meat consumption of wild game or wild boar.Laboratory analyses of pituitary function under replacement therapy 3/17: the serum levels of sodium, potassium, thyroxine, trijodothyronine and testosterone were normal, thyroid stimulating hormone was decreased as to be expected [0.05mU/1]. Insulin-like Growth Factor 1 [IGF-1]: 22.5 $\mu \mathrm{g} / 1$ [Normal range 42-187], Prolactin: 2.16 $\mathrm{g} / \mathrm{l}$ [Normal range 4-15]. At discharge, the patient was in good clinical condition. The serum transaminsases had significantly decreased. The laboratory results concerning the positive hepatitis E serology arrived in the hospital 2 days after discharge. To our surprise, the levels had risen again at the next control at $4 / 17$, although the patient was still well and had no jaundice. We immediately doubled the hydrocortisone dosage to $50 \mathrm{mg} /$ die. The liver parameters were decreasing in the end of April and had normalized in 6/17; the serum gamma GT had returned to the levels known form him before the infection (Figure 1). HEV RNA was not detected any more. The hydrocortisone dose was reduced to the dose before the acute infection within one month.

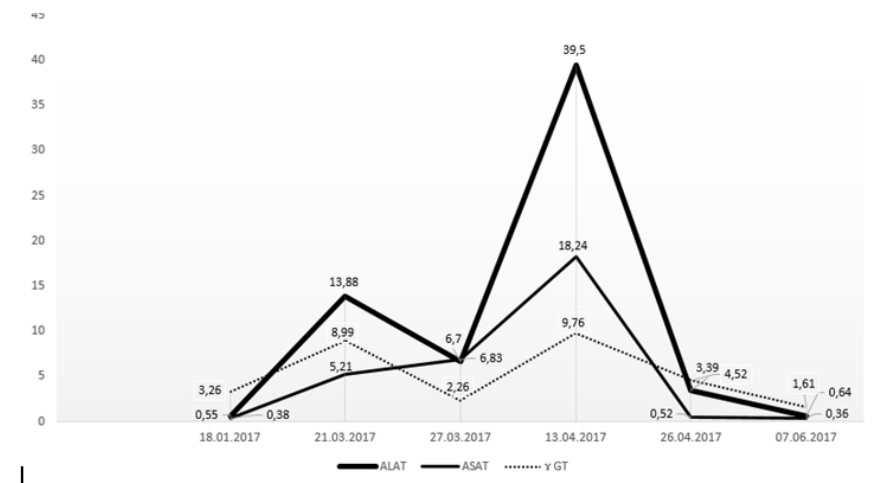

Figure I Course of serum transaminases [given in $\mu \mathrm{kat} / \mathrm{l}=\mathrm{U} / \mathrm{l}$ ] in the $75-\mathrm{yr}$ old patient with acute hepatitis E. The dose of hydrocortisone was doubled in 13.4.17.

\section{Discussion}

Several cells of the immune system have receptors for pituitary hormones suggesting interactions between the immune system and the pituitary. For example, receptors for IGF-1 and growth hormone are expressed in lymphocytes ${ }^{8,9}$ as well as receptors for prolactin. ${ }^{10} \mathrm{PRL}$ has been associated with the modulation of a variety of actions in the immune response and inflammatory processes in several physiologic and pathologic conditions. ${ }^{8}{ }^{811}$ Best characterized and well known to every physician is the effect of [endogenous] cortisone on immune function. ${ }^{12}$ However, studies in humans with isolated defects in pituitary hormone secretion or with panhypopituitarism are rare, have conflicting results and do not necessarily link an abnormal findings to clinical pathology., ${ }^{4,7,13-15}$ Furthermore, many studies have small patient numbers and no control group ${ }^{13,15}$ and focus on the impact of GH [growth Hormone] excess ${ }^{16}$ or deficiency. Table one gives an overlook of the recent literature and the findings on the topic (Table 1).

Growth hormone is not replaced in our patient due to well-being, the age and the costs of this treatment. Prolactin is not replaced in hypopituitaric patients. Although data demonstrating significantly higher infection rates in hypopituitaric patients are lacking in the medical literature, an association with their premature mortality is sometimes discussed in this context and not only as a reason of cardiovascular disease. ${ }^{17}$ We were also not able to identify medical literature reporting more complicated courses of hepatitis types $\mathrm{A}, \mathrm{B}$ or $\mathrm{C}$ in hypopituitaric patients. Data about hepatitis $\mathrm{E}$ in this context do not exist. As for other disorders, there is a trend in the studies demonstrating, that chronic or fulminant courses of HEV infection rather occur in "severely" immunosuppressed patients, such as transplant recipients or HIV infected patients. The courses in other disorders that have reduced immune response themseles or/ and are treated with immunosuppressants seem to be more benign E.g. Suzuki et al. describe the case of a patient with ulcerative colitis treated with prednisolone and infliximab. This patient had a benign self-limiting course of HEV infection. ${ }^{18}$ In a French study, 23 cases of HEV infection in patients with rheumatoid arthritis, axial spondyloarthritis, psoriatic arthritis, and other types of arthritides under immunosuppressive therapy regimens were studied. ${ }^{19}$ The treatment included discontinuation of immunosuppressants in 20 patients and ribavirin treatment in 5 patients. No chronification of the infection occurred. Although the literature gives no clear picture on the immune status of hypopituitaric patients, the replacement therapy with hydrocortisone is an important issue. It is well known, that patients with primary and secondary adrenal insufficiency require an adaptation of the hydrocortison dose in case of infection. Since the patient was in good clinical condition, we decided to double the dose, when the transaminases rose again, which is a moderate dose adaptation. It remains a matter of speculation, to which degree the dose-escalation of hydrocortisone during the infection helped to overcome the hepatitis and what would have been the course without dose adaptation. Apart from a potential negative effect of panhypopituitarism on immune function, there is also data suggesting a worse course of Hepatitis $\mathrm{E}$ in underlying chronic liver disease [NAFLD], as can be assumed in diabetic patients. ${ }^{20} \mathrm{We}$ could not identify literature on possible differences in the course of acute Hepatitis E in „NAFLD-only“patients vs. patients with a healthy liver. Another factor with negative impact on the immune response is age, our patient was 75 years old.

Table I Immunological findings in human pituitary disorders

\begin{tabular}{|c|c|c|c|}
\hline $\begin{array}{l}\text { Author, date } \\
\text { of publication }\end{array}$ & Patients/Controls & Measurements & Results in the patient group \\
\hline $\begin{array}{l}\text { Spadoni GL et } \\
\text { al. }{ }^{15}\end{array}$ & $\begin{array}{l}\text { I } 3 \text { children with GH } \\
\text { deficiency }\end{array}$ & $\begin{array}{l}\text { Analysis of lymphocyte subset patterns } \\
\text { before and during [ } 6 \text { and } 12 \text { months] } \\
\text { therapy with biosynthetic GH }\end{array}$ & $\begin{array}{l}\text { Absolute number of T-lymphocytes, T-cell subsets, natural } \\
\text { killer cell activity and response of lymphocytes to } \\
\text { polyclonal antigens all in the normal range before and } \\
\text { during therapy. }\end{array}$ \\
\hline
\end{tabular}


Table continued...

\begin{tabular}{|c|c|c|c|}
\hline $\begin{array}{l}\text { Author, date } \\
\text { of publication }\end{array}$ & Patients/Controls & Measurements & Results in the patient group \\
\hline Lebl J et al. ${ }^{13}$ & $\begin{array}{l}10 \text { young } \mathrm{GH} \text { deficient } \\
\text { adults }\end{array}$ & $\begin{array}{l}\text { Humoral [IgG, IgA, IgM, C3, C4, } \\
\text { immune complexes] and lymphocyte } \\
\text { subsets before GH therapy and } 6 \\
\text { weeks, } 3 \text { and } 6 \text { months during therapy }\end{array}$ & $\begin{array}{l}\text { "Trend" to higher CD } 4 \text { and CD } 8 \text { lymphocytes with } \\
\text { maximum change at } 6 \text { monthy of therapy. Decrease in } \\
\text { lgA and C4. „Tendency" to an increase in circulating } \\
\text { immune complexes. }\end{array}$ \\
\hline Colao $\mathrm{A}$ et al. ${ }^{16}$ & $\begin{array}{l}100 \text { patients with active } \\
\text { acromegaly; } 200 \text { controls }\end{array}$ & Analysis of lymphocyte subset patterns & $\begin{array}{l}\text { Increased levels of CD } 3 \text { and CD 4, decreased levels of } \\
C D 8 \text { and CD } 19 \text { in patients [increase in T cell activity } \\
\text { decreased B cell activity]. }\end{array}$ \\
\hline $\begin{array}{l}\text { Sneppen SB et } \\
\text { al. } .^{14}\end{array}$ & $\begin{array}{l}19 \text { adults with severe } \mathrm{GH} \\
\text { deficiency; II } 0 \text { healthy } \\
\text { adults }\end{array}$ & $\begin{array}{l}\text { Analysis of lymphocyte subsets and } \\
\text { NK cell activity before and } 18 \text { months } \\
\text { of randomized treatment with GH or } \\
\text { placebo }\end{array}$ & $\begin{array}{l}\text { NK cell activity [stimulated or unstimulated by Interferon } \\
\text { Alpha or Interleukin 2] significantly impaired in GH } \\
\text { deficient patients. No changes during therapy. }\end{array}$ \\
\hline $\begin{array}{l}\text { Mukherjee A } \\
\text { et al. }{ }^{4}\end{array}$ & $\begin{array}{l}21 \text { panhypopituitaric } \\
\text { patients under stable } \\
\text { hormonal replacement incl. } \\
\mathrm{GH} ; \mathrm{I} 2 \text { controls }\end{array}$ & $\begin{array}{l}\text { Analysis of lymphocyte subsets, } \\
\text { pneumococcal antibody levels, pre- } \\
\text { and I month after polysaccaride } \\
\text { vaccination; T-cell numbers, in vitro IFN } \\
\text { gamma response }\end{array}$ & $\begin{array}{l}\text { Lower B cell numbers in the patient group; lower } \\
\text { antibody response to polysaccaride antigen in } 9 \text { of the } \\
\text { patients. }\end{array}$ \\
\hline $\begin{array}{l}\text { Szynaka E et } \\
\text { al. }^{7}\end{array}$ & $\begin{array}{l}30 \text { children and young } \\
\text { people with GH deficiency; } \\
25 \text { healthy children }\end{array}$ & $\begin{array}{l}\text { Lymphocyte subsets and concentration } \\
\text { of } \lg A \text {, IgG, } \lg M \text { before and } 6 \text { months } \\
\text { during GH therapy }\end{array}$ & $\begin{array}{l}\text { Increase in percentage of active granulocytes after } 6 \\
\text { months, significant decrease in IgM and IgA [but within } \\
\text { normal range]. }\end{array}$ \\
\hline $\begin{array}{l}\text { Campos VC } \\
\text { et al. }{ }^{5}\end{array}$ & $\begin{array}{l}35 \text { adults with isolated } \\
\mathrm{GH} \text { deficiency; } 3 \mathrm{I} \text { healthy } \\
\text { controls }\end{array}$ & $\begin{array}{l}\text { Skin tests and response to vaccination } \\
\text { for hepatitis } B \text {, tetanus and bacillus } \\
\text { Calmette-Guerin }\end{array}$ & $\begin{array}{l}\text { Patients with GH deficiency had lower total lgG; no } \\
\text { detectable clinical impact. }\end{array}$ \\
\hline
\end{tabular}

$\mathrm{GH}$, Growth hormone

\section{Conclusion}

Although possibly compromitted by hypopituitarism, by NAFLD and the age, the immune function of the patient described here, was obviously „good enough"to overcome acute HEV infection. Other data on the course of acute hepatitis $\mathrm{E}$ in hypopituitarism have previously not been published. Whether the course of hepatitis $\mathrm{E}$ in patients with panhypopituitarism under insufficient hormonal replacement therapy is more complicated, remains to be elucidated.

\section{Acknowledgements}

None.

\section{Conflict of interest}

The authors declare, that there is no conflict of interest regarding the publication of this paper.

\section{References}

1. Hartl J, Wehmeyer MH, Pischke S. Acute Hepatitis E: Two Sides of the Same Coin. Viruses. 2016;8(11):299.

2. Yazbek S, Kreidieh K, Ramia S. Hepatitis E virus in the countries of the Middle East and North Africa region: an awareness of an infectious threat to blood safety. Infection. 2016;44(1):11-22.

3. Mukherjee $\mathrm{M}$, Helbert $\mathrm{J}$, Davis $\mathrm{S}$, et al. Immune function in hypopituitarism:time to reconsider ? Clin Endocrinol. 2010;73(4):425431.
4. Mukherjee M, Helbert WD, Ryder R, et al. Failure of antibody response to polysaccharide antigen in treated panhypopituitary adults. Clin Exp Immunol. 2009;156(2):271-277.

5. Campos VC, Barrios MR, Salvatori R, et al. Infectious diseases and immunological responses in adult subjects with lifetime untreated, congenital GH deficiency. Endocrine. 2016;54(1):182-190.

6. Kelley KW, Weigent DA, Kooijman R. Protein hormones and immunity. Brain Behav Immun. 2007;21(4):384-392.

7. Szynaka E, Petriczko E, Grabarek J, et al. Effects of recombinant human growth hormone $[\mathrm{rhGH}]$ replacement therapy on detailed immunologic parameters in somatotropine-deficient paediatrics patients prior and after 6 months of rhGH treatment. Neuroendocrinol Lett. 2010;31(4):553-558.

8. Dorshkind K, Horseman ND. The roles of prolactin, growth hormone, insulin-like growth factor-I, and thyroid hormones in lymphocyte development and function: insights from genetic models of hormone and hormone receptor deficiency. Endocr Rev. 2000;21(3):292-312.

9. Yang Y, Guo L, Ma L, et al. Expression of growth hormone and insulinlike growth factor in the immune system of children. Horm Metab Res. 1999;31(6):380-384.

10. Dardenne M, De Moraes MC, Kelly PA, et al. Prolactin receptor expression in human hematopoietic tissues analyzed by flow cytofluorometry. Endocrinology. 1994;134(5):2108-2114.

11. Pereira-Suarez AL, Lopez-Rincon G, Martinez-Neri PA, et al. Prolactin in inflammatory response. Adv Exp Med Biol. 2015;846:243-264.

12. Cooper MS, Stewart PM. Corticosteroid insufficiency in acutely ill patients. N Engl J Med. 2003;348(8):727-734. 
13. Lebl J, Sediva A, Snajderova M, et al. Immune system in adults with childhood-onset growth hormone deficiency: effect of growth hormone therapy. Endocr Regul. 2000;34(4):169-173.

14. Sneppen SB, Mersebach $\mathrm{H}$, Ullum $\mathrm{H}$, et al. Immune function during GH treatment in GH-deficient adults: an 18-month randomized, placebocontrolled, double-blinded trial. Clin Endocrinol. 2003;57(6):787-792.

15. Spadoni GL, Rossi P, Ragno W, et al. Immune function in growth hormone-deficient children treated with biosynthetic growth hormone. Acta Paediatr Scand. 1991;80(1):75-79.

16. Colao D Ferrone, Marzullo P, Panza N, et al. Lymphocyte subsets in acromegaly. J Endocrinol Invest. 2002;25(2):125-128.

17. Tomlinson JW, Holden N, Hills RK, et al. Association between premature mortality and hypopituitarism. West Midlands Prospective Hypopituitary Study Group. Lancet. 2001;357(9254):425-431.
18. Suzuki K, Kumagai I, Yoshida Y, et al. Asymptomatic acute hepatitis $\mathrm{E}$ in a female patient with ulcerative colitis. Clin J Gastroenterol. 2017;10(3):255-260

19. Bauer H, Luxembourger C, Gottenberg JE, et al. Outcome of hepatitis E virus infection in patients with inflammatory arthritides treated with immunosuppressants: a French retrospective multicenter study. Medicine [Baltimore]. 2015;94(14):675.

20. Singh KK, Panda SK, Shalimar SK, et al. Patients with Diabetes Mellitus are Prone to Develop Severe Hepatitis and Liver Failure due to Hepatitis Virus Infection. J Clin Exp Hepatol. 2013;3(4):275-280. 